\title{
QIKJS-Part.0.A
}

\section{Qualitative Inquiry of Korean Judicial System}

\author{
Kiyoung Kim \\ Professor of Law and Public Policy \\ Dept. of Law, Chosun University \\ Gawng-ju South Korea
}

\section{Introduction}

Along the way toward the dissertation process, we know that the scholarly work in same concern is important to structure the theme and empirical work for the dissertators. In other words, the literature review is a critical part that defines the attribute and creativity of doctoral research. Since the theorists reflected in the work of dissertation are the kind of influential scholars in the field -- or even philosophical and interdisciplinary, their views can well be received as a touchstone in terms of proposition, advocacy, comparison, development and criticism. The impact of these scholars would be built on the life-time devotion that allows us some important perspective to develop the work of dissertation. In this context, the website designed to illustrate the important thinkers and theorists on the discipline of public administration is very helpful (Toavs, 2014). With this kind of influence, we would be just a worker on the empirical work, say, data collection and analysis that should eventually be developed as the kind of epithet combined with the reality and views of dissertator as well as such theorists for the social change. Since I just completed the methodology class, this class actually is very exciting to view the whole picture of doctoral works.

My interest in the doctoral dissertation attempts to explore the topic of public administration of Korean judiciary in which I will use the theoretical framework developed with the insight of several philosophers or theorists. They are important to analyze the historical event and transformation, and develop my theme or stories with suggestion for any better nature of public policy involved with the judicial branch. Since the public administration of judicial branch is interwoven with the arena of politics and constitution, the views of Montesquie and United constitution, as well as the view of Goodman F. on the public policy and law would be a basic lens to analyze the phenomena (Montesquieu, Cohler, Miller, Stone, 1989). Their view is central to characterize such work that my empirical work on data collection would include the indepth interviews of 10-20 jurists of Korea and documentation from the newspaper articles, public record as well as scholarly articles and books of Korean origin, vastly qualitative, but with some of quantitative data. The second group of philosophers would be the kind of more modern thinkers of government that was based on the first group, but with adaptation and new perspectives to incorporate the transformation of democratic government. Goodman F, the philosopher of law and public policy, would be one of notable figures leaving a wake of influence on the area of my research interest. 
The third group of thoughts most pertinent to look into my research queries would be indebted to the theorists of rational choice, most notably P Sabatier and E. Ostrum, that their view is a useful framework for analyzing a wide variety of questions -- of course, as expected to deal with the dissertation project. ${ }^{1}$ One other similar approach was found in Allen Shick who is a governance fellow of the Brookings Institution and also a professor of political science at the Maryland School of Public Policy, University of Maryland. His thoughts may also be viewed as same ethos with Goodman since it deals with the public policy, implying that is not always shared with the rational option, but cultural and political in some aspect. Then we may place three groups of influence in spectrum of rigidity and flexibility index that the first group is most rigid, while the second comes next and the third lies in other next. In other words, the first may be closest to the law and structure, and the second as closest to the attribute of public, while the third being tended of economics.

\section{The First Group of Philosophers}

With respect to my research topic, Montesquieu and US Constitution come most dominant in narrative and discourse that the public administration of judicial branch must be subject to the provisions of constitution and judicial acts (1989). That may be shared to the extent with other branches of government, but should be distinct since the judicial branch is characteristic of passivity in function than the two other brother branches. This aspect impels the separation of powers principle as a central concept and plays as ballast through data analysis and my bracketing to construct a theme and stories of Korean judiciary. The ideas from two sources actually would be original and sparked a foundational reshuffling from the ancient regime. Their theme is functional and institutional to restructure the government to adapt with the transformation of economic relations and social class (Buchanan \& Badham, 2009). In terms of economic relations and social class, the thought and practice generally had been given the kind of order - three estates of French Monarchy called the clergy, the aristocracy and the people at large represented by the Estate-General - even through the last vestige of feudal structure. This means that the politics of Monarchy had been absolute, thus simple, and based on the ethics and tradition of state, which saw no needs of such functional and institutional formula to address the new challenges arising from the new economic and social relations. Hence, his idea on the trias of politica, monarchy,

\footnotetext{
1 For example, the Institutional Analysis and Development (LAD) framework can be modified to address the important set of questions culturally. Charlotte Hess and Ostrum organized a conference and coedited a book that examined some aspects of the knowledge commons using the IAD framework.' The theory is so adaptable to have various applications by incorporating the aspects of cultural environments. Korean case can be thought of as "cultural commons" in this understanding. However, the tension for truths underlying in this marriage is considerable that many important questions related to the study of cultural commons await a careful institutional analysis. It is despite the fact that the cultural products (e.g., new knowledge or software) are often available to many users who do not have to pay the producer in order to use those products. Hence the cultural marriage into the kind of commons in view of this universal character of LAD proposition is difficult work to be engrafted. It is especially challenging in tension with the first group of thought in dealing with the public administration of judiciary given the extent nature of cultural elements - often said as political or normative, but cultural if with the rational choice theory -- within the constitutional rule.
} 
aristocracy and commons, is revolutionary by completely eliminating the basis of ancient regime. This is the kind of elaboration on the super-structure -- but very resilient and generally embedded in practice through modern flourishing of capitalism - in contrast with Marxism, who perceived the essences of human, social, political relations from the viewpoint of low structure, say, economic relations. Even his idea partly was with the sense of feudal nobility, but had been continued on the modern constitutionalism. The service of his views and propositions are deeply embedded in the concept of limited government, which is presumed of human right protection and against the arbitrary power with the check and balance mechanism. In some aspect, the balance of power from his experience in Britain was moderated with his parted mind to hold the conservative ethos and necessary extent of control of power. The kind of observations he made over his period of time are indeed influential for the discipline that he also cast seminal ideas of interdisciplinary nature ${ }^{2}$ - such as economics, anthropology and climate, primogeniture and leadership qualities -- which is crucial so that the students of public administration should be dynamic and progressive beyond the passive application of laws. He also was a good futurist with conscience and criticism that is an important attribute for the social change makers. For example, he outlined a satirical hypothetical list of argument for slavery that saw the state of slavery as bad. The description above could be churned over his chronological works (i) Spicilège (Gleanings, 1715 onward) (ii) Système des idées (System of Ideas, 1716) (iii) Lettres persanes (Persian Letters, 1721) (iv) Le Temple de Gnide (The Temple of Gnidos, a novel; 1725) (v) Histoire véritable (True History, a reverie; c.1723-c.1738) (vi) Considérations sur les causes de la grandeur des Romains et de leur décadence (Considerations on the Causes of the Greatness of the Romans and their Decline, 1734) at Gallica (vi) Arsace et Isménie (Arsace and Isménie, a novel; 1742) (vii) De l'esprit des lois ((On) The Spirit of the Laws, 1748) (volume 1 and volume 2 from Gallica) (viii) La défense de "L'Esprit des lois» (In Defence of "The Spirit of the Laws", 1750) (ix) Essai sur le goût (Essay on Taste, pub. 1757) (x) Mes Pensées (My Thoughts, 1720-1755).

The discourse and research subjects in my case are fairly taunted on the basis of functional and institutional narratives than economic and social factors. This is a distinct element in view of public administration of judicial branch (Kim, 2015 a; 2015 b; 2014) Often they came with the public perception of nobility socially, and perhaps most of reliable government organ for the enterprises and property owners economically. They often are attributed as conservative mostly that defends the community on the principle of stare decisis. The public administration of judiciary, therefore, can fit with some type of exotic scene that could be shed in other particular light as historically charted over the Korean history (Barnard, 1938). In other words, the public policy of personnel resources,

\footnotetext{
2 Louis Althusser, for example, alluded to the seminal character of anthropology's inclusion of material factors, such as climate, in the explanation of social dynamics and political forms. John Maynard Keynes also described Montesquieu as "...the greatest of your economists, head and shoulders above the physiocrats in penetration, clear-headedness and good sense."
} 
budget, and organizational role - considered central points of contention -- in the judiciary and especially for the Korean case can only be investigated as if we research the minority or intact cultural group. This can be compared in distinction with other branches of government and public organization in general. At the core of concept and their episode lies in the value of judicial independence. The judiciary over the history had featured in turbulence with different public perception and awareness, such from the lawyers as evil technician through the bulwark of human rights or justice for the minority deprived from the abuse of politics. The elements of organization stem from this general attribute and public sense, which provides a theme of my research. The context can be deeper in the wake of global spread of liberal democracy, and Korea is surely the one of this progenies. The Korean ailment for the judicial independence and historical aspiration for the original function of separation of powers principle are deeply intertwined with unpredictable or biased public administration of judiciary (Blau, \& Scott, 1962). The story for such short period of democracy in Korea might approach as a Shabbat for the westerners that had been a compressed development with struggles, which would be less sensible for the people in the common law tradition - if struggled in much more lengthier time span from Sir Coke, inauguration of US constitution and through the court packing plan in earlier of last century.

\section{The Second Group of Philosophers}

Given the studies of government and administration are not the kind of universal discourse unlike other subjects on humanity and social science, the kind of thought had merely been tacit and intramural with the cadres of government although the theme is a vertebrate of government to be held with the binding force. In other words, the academic elaboration generally lacks to affect the scholarly circle because of its national particulars and contingencies as less amenable to the general sharing, which is not same with the psychology or sociology and general political discourse. Thankfully with the contributions of F.J. Goodnow around the turn of last century, my research theme can be assisted more with a practical adaptation and reflection of US progress beyond the formula or hash tag of simple classic frame above (Crozier, 1964). As known, the US constitutionalism had been imported by many new born republics and the core ideas embedded in the document actually had exerted much influence for those countries institutionally and politically. In this backdrop, the philosophy and instruction of Goodnow had a wide of influence on the discipline and much potential to guide my research for the public administration of Korean judiciary. Goodnow had been a professor of administrative and constitutional law at Columbia University, who also had a rich career as a university and city administrator. He was the first president on the organization of the American Political Science Association in 1903, and a member of President Taft's Efficiency and Economy Commission in 1912, and the boards of the Brookings Institution and the Institute of Government Research. This profile is very suited to the character of theme, i.e., public administration of judiciary that represents 
the right wing ethos and nobility of nation leading the public (1964). Dr. Goodnow's scholarly publications are considerable in volumes that constitute a substantial library; (i) The Tweed Ring in New York City in the first edition of Bryee's American Commonwealth (ii) Two articles in the Political Science Quarterly and (iii) many others in the Proceedings of the National Municipal League, American Political Science Association, American Political Science Review, Columbia Law Review and other periodicals. He also wrote many books, to list, comparative Administrative Law, Municipal Home Rule, Municipal Problems, Politics and Administration, City Government in the United States, Principles of the Administrative Law in the United States, Selected Cases on the Law and Taxation, Government and Administration, The Law of Officers, Municipal Government, Social Reform and Constitution, Principles of Constitutional Government, China, an Analysis, and the American Conception of Liberty and Government. Goodnow is a legal scholar in origin, but had been much attuned with the attitude of social scientists as transcending the general rigidity of law and clerical tones of work. He had been practical and the kind of messenger inspired both with the law in books and law in action spirit (March, 1966). The comments and evaluation from peer scholars hint on his scholarly character, which are malleable to the discipline of public policy and administration. We can know some of important trait from them, which are a physiology, ${ }^{3}$ enthusiasm for the organized movement, ${ }^{4}$ evolutive interpretivism and social reform, as well as his character, personality and intellect. ${ }^{5}$ These are the points of surety we can see as precious for the import of ideas from the department of law. For example, a physiology impresses the transformative nature of public arena that can be made better and improved with practical effect, the very idea of public policy than a mere application of law.

\section{The Third Group of Philosophers}

With respect to the public administration, it is hardly deniable that the policy

\footnotetext{
${ }^{3}$ His general characteristic had been viewed by Powell, "Emphasis is laid by Dr. Goodnow on the physiology rather than the anatomy of government. His essentially practical mind has been quick to see that it is of prime importance to discover how the mechanism of government actually operates...His is a study of dynamics."

${ }^{4}$ M. Smith commented on his works, "it is in reality a contribution to what Ballot-Beapture has happily termed evolutive interpretation. He continued, "He has many of the best traits of the purely academic investigator; a skeptical attitude toward traditional theories... To him a fact is of little moment unless it proves something that is worthwhile and a theory is important only in view of its effects upon social life.

5 Dr. C.A. Beard summarized the accomplishments, "Mr. Goodnow was the first scholar in the United States to recognize the immense importance of administration in modern society and to sketch the outline of the field.... Not content with the law of his subject, he went behind the scenes to explore the nature and operations of politics in relation with administration..." His comment is insightful for the qualitative researchers on the public administration, "But ever inquiring, Mr. Goodnow carried his analysis over into the amazing jurisprudence of constitutional law and disclosed in that mysterious domain (once generally supposed to be mathematical) the operation of sentiments, institutions, and opinions."
} 
makers are essentially constrained with the efficiency concept. This leads to the fact that their resort to weigh a specific policy often relies on the exploration of rational choice. Hence, the LAD and similar ideas developed by many scholars under the scholarship of E. Ostrum -- a central figure in this framework and nobelist of economics -- can exert an influence on the discipline. Her perspective and philosophy are particularly contributive since it can be practical by incorporating the actors and players in the real institutional settings (Meyer \& Rowan, 1977). This idea would be less prevalent that may not dominate the discourse of Korean judiciary since the nature of theme is rather political and had been on struggle for the judicial independence. In other words, we note in my case that the moral narrative or political and normative discourse would constitute the vantage point of qualitative inquiry than rational option or efficiency of institutions. Nevertheless, the theory or framework of thought could be an influence in certain area, such as the development of public counsel system for the deprived clients or affordable budgeting in the face with the fiscal challenge of government. The scholarship also expects of expansive application with the cultural variations that can be pertinent to the research. The LAD was grounded on the game theory so that it is the kind of applied nature to be adapted with the reality of modern institutions. According to her introduction, the game theory is posited with the basic assumptions and relevant structural elements. ${ }^{6}$ The theory can predict the outcome and the LAD has a strength that the working parts of a game are best conceptualized as the universal working parts of an "action situation" (Scott, 2008). She also introduced the outline of her rules, which is fairly instructional to guide the discipline of public administration. The epitomes come in summary (i) Boundary rules that specify how actors are to be chosen to enter or leave a situation (ii) Position rules that specify a set of positions and how many actors hold each one (iii) Information rules that specify channels of communication among actors and what information must, may, or must not be shared (iv) Authority rules that specify which actions are assigned to a position at a node (v) Aggregation rules (such as majority or unanimity rules) that specify how the decisions of actors at a node are to be mapped to intermediate or final outcomes (vi) Scope rules that specify the outcomes that could be affected (vii) Payoff rules that specify how benefits and costs are to be distributed to actors in positions. The thought on these elements provide a lens of analytical work for the public administration of Korean judiciary beyond the general impact on the discipline. For example, the authority rules can be applied to the strong leadership of national head -- or even viewed as dictatorship of predicament years of Korean judiciary - that the judiciary was to be enslaved into the theme of national development. Aggregation rules may give an insight and solution that the demised constitutions and governance on that basis were to be mapped to intermediate or final outcomes, such as no civilian justice and manipulation of judicial responsibility. In this way, the frame can be a guide to see the

6 1. number of actors; 2. positions they held (e.g., row or column player);3. amount of information available to an actor; 4. set of actions that actors could take at specific nodes in a decision tree; 5 . set of functions that mapped actors and actions at decision nodes into intermediate or final outcomes; 6. outcomes that actors jointly affected; and 7 . benefits and costs assigned to actions and outcomes. 
intrinsic of PA for the Korean judiciary. The other aspect of LAD theory to deal with constructing cultural commons in cultural environments can be useful to look into the recent reform between the paradigm of public exam and law school only about production of new attorneys (Rice, Mitchell, Mathews, 2012). The law school culture originated from the US institutions and the public exam had been based on the European or Asian traditions. Adoption of one alternative can generate productive or adverse incentives for participants. In short, her theory is influential as she introduced, "Madison, Frischmann, and Strandburg have opened a large and productive research agenda for scholars from many disciplines who are interested in how governance arrangements in diverse cultural commons affect outcomes." Her idea and propositions or theories can be more deeply read with her selected publications; (i) Governing the Commons: The Evolution of Institutions for Collective Action published in 1990 (ii) Institutional incentives and sustainable development: infrastructure policies in perspective in 1994 (iii) Trust and reciprocity: interdisciplinary lessons from experimental research in 2003 (iv) Understanding institutional diversity in 2005 (v) Understanding knowledge as a commons: from theory to practice in 2008. It is also helpful that her journal publications include (i) "A grammar of institutions," published in the American Political Science Review (ii) "A behavioral approach to the rational choice theory of collective action: Presidential address, American Political Science Association, 1997" (iii) "Beyond markets and states: polycentric governance of complex economic systems" in the American Economic Review. 


\section{References}

Barnard, C. I. (1938). The functions of the executive. Cambridge, MA: Harvard University Press.

Blau, P. M., \& W. R. Scott (1962). Formal organizations: A comparative approach. San Francisco, CA: Jossey-Bass.

Buchanan, D. A., \& R. J. Badham.(2009). Power, politics, and organizational change. Thousand Oaks, CA: Sage.

Crozier, M. (1964). The bureaucratic phenomenon. Chicago, IL: University of Chicago Press.

Kim, Kiyoung, Ethics, Law and Social Justice (April 10, 2015a). Available at SSRN: https://ssrn.com/abstract=2592876 or http://dx.doi.org/10.2139/ssrn.2592876

Kim, Kiyoung, Public Policy and Governance: Some Thoughts on Its Elements (April 3, 2015b). Available at

SSRN: $\underline{\text { https://ssrn.com/abstract=2589526 or http://dx.doi.org/10.2139/ssrn.2589526 }}$

Kim, Kiyoung, The Relationship between the Law and Public Policy: Is it a Chi-Square or Normative Shape for the Policy Makers? (September 10, 2014). Social Sciences. Vol. 3, No. 4, 2014, pp. 137-143. doi: 10.11648/j.ss.20140304.15. . Available at SSRN: $\underline{\text { https: } / / \text { ssrn.com/abstract }=2577832}$

March, J. G. (1966). The power of power. In David Easton, ed., Varieties of political theory (pp. 39-70). Englewood Cliffs, NJ: Prentice Hall.

Meyer, J. W., \& B. Rowan (1977). Institutionalized organizations: Formal structures as myth and ceremony. American Journal of Sociology, 83, 340-363.

Montesquieu, C., Cohler, C., Miller, B.C., Stone, H.S. (1989). Montesquieu: The Spirit of the Laws, UK: Cambridge University Press.

Rice, Mitchell F. \& Audrey L. Mathews (2012). A New Kind of Public Service Professional: Processing Cultural Competency Awareness, Knowledge, and Skills, In Kristen A. Norman-Major and Susan T. Gooden, eds., Cultural Competency for Public Administrators, (pp. 19-31). Armonk, NY: M. E. Sharpe.

Scott, W. R. (2008). Institutions and organizations: Ideas and interests, 3rd ed. Thousand Oaks, CA: Sage.

Toavs, D. (n.d.). Ideas of governance. Retrieved August 25, 2014, from http://www.tikitoki.com/timeline/entry/146482/Ideas-of-Governance 